\title{
In QUEST of TOLSTOY
}


Studies in Russian and Slavic Literatures, Cultures and History

Series Editor: Lazar Fleishman

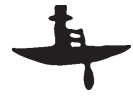

Academic

Studies

Press 


\section{In QUEST \\ of TOLSTOY}

Hugh McLean

Boston

2008 
Library of Congress Cataloging-in-Publication Data

McLean, Hugh, 1925-

In quest of Tolstoy / Hugh McLean.

p. cm. - (Studies in Russian and Slavic literatures, cultures and history) Includes bibliographical references and index.

ISBN 978-1-934843-02-4 (hardcover)

1. Tolstoy, Leo, graf, 1828-1910-Criticism and interpretation.

2. Tolstoy, Leo, graf, 1828-1910-Influence. I. Title.

PG3410.M35 2008

891.73 '3 - dc22

2008000960

Book design by Yuri Alexandrov

Published by Academic Studies Press in 2008

145 Lake Shore Road

Brighton, MA 02135, USA

pressaacademicstudiespress.com

www.academicstudiespress.com 


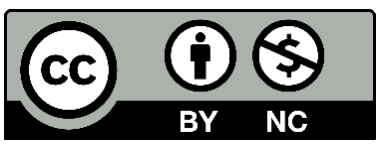

Effective December 12th, 2017, this book will be subject to a CC-BY-NC license. To view a copy of this license, visit https://creativecommons.org/licenses/by-nc/4.0/. Other than as provided by these licenses, no part of this book may be reproduced, transmitted, or displayed by any electronic or mechanical means without permission from the publisher or as permitted by law.

The open access publication of this volume is made possible by:

THE

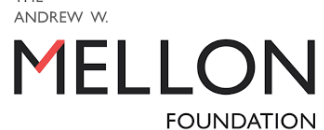

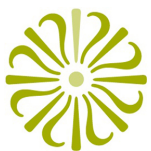

NATIONAL ENDOWMENT FOR THE HUMANITIES

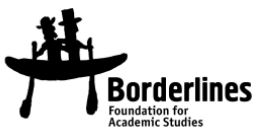

This open access publication is part of a project supported by the National Endowment for the Humanities and The Andrew W. Mellon Foundation Humanities Open Book initiative, which includes the open access release of several Academic Studies Press volumes. To view more titles available as free ebooks and to learn more about this project, please visit borderlinesfoundation.org/open.

Published by Academic Studies Press

28 Montfern Avenue

Brighton, MA 02135, USA

press@academicstudiespress.com

www.academicstudiespress.com 